\title{
Interfaces
}

INTERFACES Image Texte Language

$44 \mid 2020$

Les manières de faire vernaculaires

\section{Amiri Baraka - Militant Writer and Artist}

\section{Donald Friedman}

\section{(2) OpenEdition}

\section{Journals}

Electronic version

URL: http://journals.openedition.org/interfaces/1926

DOI: 10.4000/interfaces.1926

ISSN: 2647-6754

\section{Publisher:}

Université de Bourgogne, Université de Paris, College of the Holy Cross

\section{Printed version}

Date of publication: 15 December 2020

Number of pages: 171-175

ISSN: 1164-6225

\section{Electronic reference}

Donald Friedman, «Amiri Baraka - Militant Writer and Artist », Interfaces [Online], 44 | 2020, Online since 15 December 2020, connection on 21 December 2020. URL : http://journals.openedition.org/ interfaces/1926 ; DOI : https://doi.org/10.4000/interfaces.1926

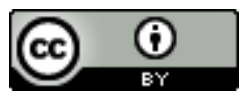

Les contenus de la revue Interfaces sont mis à disposition selon les termes de la Licence Creative Commons Attribution 4.0 International. 


\title{
AMIRI BARAKA - MILITANT WRITER AND ARTIST
}

\author{
Donald Friedman
}

Donald Friedman interviewed Amiri Baraka (1934-2014) in 2003. An edited excerpt of that interview may be viewed at https://donaldfriedman.com/2019/06/25/amiri-baraka-politics-exists-fortruth-and-beauty/

Below are an introduction to the interview and a full transcript of the excerpt.

\section{Introduction}

A political figure whose words were angry, often incendiary, occasionally homophobic, misogynistic and anti-Semitic, Amiri Baraka used his writing first and foremost as agitprop, as a means to change. As he said in this interview, for him the value of art lay in its content.

But it's always like that with us, art, politics, you know, in our family. I guess we see them holding hands. You have to strive to be politically revolutionary or progressive, but also artistically powerful... The question is, finally, 'What is it saying?' Because content is more important to me than form.

Yet at some point Auden's admonitory "poetry makes nothing happen" must have registered with Baraka and his words were augmented by his becoming politically active, organizing to replace corrupt officials and establishing community-based social projects in his hometown of Newark, New Jersey. When we met in 2003 I expected hostility — at least emotional chilliness — and was quite unprepared for the warm, open, joyful man I encountered. Baraka was full of laughter and humble enough to direct a lot of it at himself.

I did, however, get a taste of his anger after he read his entry in my book The Writer's Brush: Paintings, Drawings, and Sculpture by Writers and challenged my having joined the large chorus that condemned his 2002 poem "Somebody Blew Up America" as anti-Semitic and which ultimately caused him to lose his position as Poet Laureate of New Jersey. Baraka at that point had a history of anti-Semitic writing going back 50 years. In an early essay he wrote "I got the extermination blues, 
jewboys. I got the hitler syndrome figured ... So come for the rent, jewboys ... one day, jewboys, we all, even my wig wearing mother gonna put it on you all at once."

Baraka denied being an anti-Semite, or a homophobe. A statement like his "Most American white men are trained to be fags," or his declaration in "Black People" that Blacks cannot succeed "unless the white man is dead," and his call to Black people "to get together and kill him," he justified as merely vernacular expression, a way to give voice to Black oppression. (Beginning with his 1963 essay "Expressive Language," Baraka insisted that an artist must create with the language specific to her culture.)

The goal of his political efforts, he declared at the start of our conversation, was "to make room for art, to finally, you know, to make room for things that are beautiful and true.... That's what politics finally is, to do--it's to protect truth and beauty. There's no other reason." Whether one can find such a connection in his ugly polemics I leave to the viewer.

Amiri Baraka had painted and drawn since childhood, when his mother, anxious to encourage her children in any of the arts, sent him for lessons. His paintings, often of jazz musicians - Baraka was a prominent and polemical jazz critic - were exhibited frequently, most notably at the Aljira Gallery in Newark.

Among the hundreds of writer-artists featured in The Writer's Brush, there are those who draw a sharp line between the visual and literary ("Paintings shouldn't even have titles - the title of a painting should be another painting," insisted Eugene Ionesco), those like Dante Rosetti who wrote poems to accompany their paintings, and those who, like Baraka, incorporate words into the image. His paintings interweave text, often verses or verse fragments, but always vernacular.

In this interview Baraka shows how he adds words to image or builds an image around words already on the page. He likes the random juxtaposition, the effect of chance. His art eschews the tightly controlled and polished in favor of the looser and more passionate-the Impressionists rather than Vermeer, T. Monk rather than J.S. Bach. As Victor Hugo began a work by pouring the dregs of his morning coffee and some fireplace ash on the page, or Strindberg, seeking to make "natural art," said he attempted to paint "in the same capricious way as nature, without a goal," Baraka applied paint to a list of errands, to surround a FedEx number, or to any random paper at hand. Like the Dadaists, he created by consciously imposing his skills and imagination on that chance writing. He said:

I didn't decide what any of this stuff was going to look like. A lot of things happen that you had no way of predicting, you know what I mean, things - they can be 1,000 miles apart, you don't mean like that, the Titanic and that glacier, you know what I mean, but I mean... you know, nobody is saying 'God is 
doing this,' but they were on the same path. You know, Monk sums it up best. Monk says : 'There's two kinds of mistakes, the regular ones and the ones that sound bad.' You can always make a mistake, I mean, Jesus, it's nothing perfect, you're always to [sic] 'Oh boy, that sound great, we'll do that again.

A poet, playwright, novelist, essayist, music critic, actor, political activist, and the leading figure of the Black Arts movement in the United States, Baraka was born in 1934 and known until 1968 as LeRoi Jones. Baraka's father was a postman, his mother a social worker, and he was raised with middle-class values, although, as one of only a few Black students in a White high school, with a strong sense of personal alienation. After a stint in the air force as a gunner on a B-36, and a dishonorable discharge for communist sympathies, Baraka moved to Greenwich Village and, with the support of Allen Ginsberg, immersed himself in the Beat scene. In 1958 he married Hettie Cohen and with her founded and edited the avant-garde literary magazine Yugen and Totem Press, a small press publishing Ginsberg, William Burroughs, Jack Kerouac, Philip Whalen, and others.

In 1965 he left his wife and children ("How could someone be married to the enemy?"), and relocated to Harlem where he founded the Black Arts Repertory Theatre/School, which for a short time produced plays for Black audiences. He soon moved back to Newark and in 1967 married Sylvia Robinson, now known as Amina Baraka, and died there in 2014.

Baraka published some thirteen volumes of poetry, two novels, nine non-fiction works, including Blues People: Negro Music in White America (1963). Among his awards and honors are the Longview Award for Cuba Libre, the Obie Award for his play Dutchman (1964), a Guggenheim Fellowship (1965-66), Doctorate of Humane Letters, Malcolm X College, Chicago (1977), and election to the American Academy of Arts and Letters (2000).

\section{Interview transcript}

https://donaldfriedman.com/2019/06/25/amiri-baraka-politics-exists-for-truth-and-beauty/

\section{Politics is to Protect Truth and Beauty}

Why we are involved in politics - to make room for art, to finally, you know, to make room for things that are beautiful and true. Because otherwise there are forces that would destroy it all the time, you see. That's what politics finally is to do--it's to protect truth and beauty. There's no other reason. 


\section{Painting Expands Consciousness}

My mother sent me to art school when I was about 12, 13. Painting is something that expands my own consciousness of the world. It makes me more conscious of things other than words. That's what I do in my spare time-I doodle. The only thing I'm doing different is I have colors. I've done this all my life. Although I must say that I've gotten much better at it, since I'm concerned about it. Because I can see, you know, I can look and see that it actually takes... what it takes is time to do it. You have to do things over and over again, you know, you have to do them over and over again. And then you become informed about that, you know, that means...informed, that is you don't have to go through a lot of changes in...It's formed in your head, you know, in your whatever system it is that reacts to make things.

\section{Content Over Form}

But it's always like that with us, art, politics, you know, in our family. I guess we see them holding hands. You have to strive to be politically revolutionary or progressive, but also artistically powerful. Everybody can paint pretty, or paint interesting, or paint complexly, or paint ugly, or whatever you want to say. The question is, finally, "what is it saying?" Because content is more important to me than form.

\section{Words vs Paint}

I can think of words that make me happy or make me cry or make me long for things, you know what I mean. It's not that easy with painting, 'cause I don't know the materials as well. Language I know. So I know what I can do with that a little quicker. You plod on you know, you plod on until it looks like something you want. If you don't like it, you tear it up. Same thing with poetry.

\section{Words Become Image}

The only reason I would put text on it is because it seems like it wants it, you know. Maybe there's an empty space or maybe I wrote something on it beforehand that looks good like that. Look, this was...that's a real phone number, it's also nice up there, you know, because it adds something that's totally, you know, out of the question. FedEx I mean, who gives a damn about FedEx, you know what I mean. But in that context, Famous Nobodies, well, one of them is FedEx. 


\section{Chance in Creation}

I didn't decide what any of this stuff was going to look like. A lot of things happen that you had no way of predicting, you know what I mean, things - they can be 1,000 miles apart, you don't mean like that, the Titanic and that glacier, you know what I mean, but I mean...you know, nobody is saying "God is doing this", but they were on the same path. You know, Monk sums it up best. Monk says : "There's two kinds of mistakes, the regular ones and the ones that sound bad" [laughs]. You can always make a mistake, I mean, Jesus, it's nothing perfect, you're always to "oh boy, that sound great, we'll do that again." 
